\title{
A Study on Perception and Awareness on Credit Cards among Bank Customers in Krishnagiri District
}

\author{
Dr.S.SUDHAGAR \\ Assistant Professor of Commerce, MGR College/Periyar University, India.
}

\begin{abstract}
A credit card is a small plastic card issued to users as a system of payment. It allows its holder to buy goods and services based on the holder's promise to pay for these goods and services. The issuer of the card creates a revolving account and grants a line of credit to the consumer (or the user) from which the user can borrow money for payment to a merchant or as a cash advance to the user.
\end{abstract}

Keywords: Attitude, Awareness, Credit card, Cardholders and Perception

\section{Introduction}

\subsection{Origin of Credit Cards}

On February 28, 1950 - A Diners club card, the first multiuse credit card was issued. This marked the beginning of the era of plastic money. Diner's card was launched in the Indian market in 1960. The Central Bank of India was the first bank in the country to introduce credit card system in August 1980, followed by several other banks. In India, both foreign and Indian banks are doing credit card business.

The foreign banks have a dominant share due to various reasons like having been in the field for decades, sound operational and financial strength, strong brand reorganization etc. Later, with the aggressive entry of SBI, ICICI, and HDFC Banks the rules of the game changed. Among the banks issuing credit cards, the esteemed and well published cards are Citibank Diner's Club Card, Citibank Visa Card and Credit Cards, Bank of Baroda's Master Cards, the SBI Credit Cards, Bank of India's India Card, Canara Bank's Can Card and ICICI Bank's ICICI Card. These cards are positioned in a manner which gives an impression that the cards can be acquired by people from not only the upper class but also the middle income categories. The new private sector banks like ICICI and HDFC have adopted a strategy of reaching lower down the income strata by lowering down their eligibility norms. Today credit card industry is highly competitive and almost all the banks are offering credit cards in association with Visa International or Master Card.

\subsection{Current Trends in Credit Card Industry}

There is now a flood of Indian banks offering credit cards to the potential customers. Multinational banks operating in India have also joined the bandwagon with high voltage advertising and seemingly competitive reward programmes for loyal credit card users. Banks' income from credit cards can be divided mainly into four components namely annual fee, interchange charge, revolving fee (interest charged for revolving credit) and other fees. Indian credit card market is growing at almost 30 to 40 per cent annually and the number of credit cards in circulation is twenty seven and half million as reported by credit card issuers.

\section{Statement of the Problem}

Credit cards have changed the way people look at money. Gone are the days when only the rich sported them at limited counters in select cities. Today, they are a way of life for the middle class too, even in smaller locations across the country. However, this boom has brought in a lot of complications like credit card fraud, payment defaulting, unsolicited card, uncontrolled spending etc.

Rapid credit card growth has increased transaction efficiency. Till recently, the Indian consumer was using the credit card during the crunch season, but things have changed in the recent past with the consumers using it for as small a sum as Rs. 100 to over one lakh rupees. The most common feature among the credit card holders is that they carry forward their payment. Postponing payments multiplies bills that too at a whopping rate of 50 to 60 per cent per year, pushing the card holders into a debt trap.

The utility of cards varies from person to person depending on their profile. In the initial years, the consumers deem it a privilege to hold credit cards. However, there is a feeling among card holders that the banks are charging hefty interest and other fees. Credit card issuers charge interest which works out to roughly 42 per cent per annum. Delays or defaults result in payment of penal interest on all incremental usage of the card till the payments are made. Once the outstanding piles up, it can be a serious hazard to one"s financial security. Today, competition among credit card players is intense. Offering benefits like reward points is just another way of luring customers into debt trap. The biggest problems arise when one gets into what is called revolver mode of repayment. 


\section{Scope of the Study}

The present study focuses on the perception of card holders towards credit cards. The study was designed to gain a better understanding of the factors influencing possession of credit cards and card holders' satisfaction. The study also analyses the extent of utilization of credit cards by card holders and the level of awareness of bank customers not having credit cards about such cards.

\section{Objectives of the Study}

The objectives of the study are:

a) To study the awareness of bank customers about credit cards.

b) To assess the eligible credit limits and the actual credit limits availed by the card holders.

c) To examine the extent of usage of credit cards by card holders.

d) To find out the attitude of card holders towards credit cards.

e) To offer suggestions for further improvement.

\subsection{Hypotheses}

\section{Research Methodology}

a) There are no significant differences in the mean satisfaction scores of the card holders holding different brands of credit cards.

b) Mean satisfaction scores of card holders do not differ significantly according to the differences in their eligible credit limit.

c) Size of family and extent of usage of credit cards are not significantly associated.

d) There are no significant differences in the mean satisfaction scores of the credit card holders differing in their attitude towards credit cards.

\subsection{Research Design}

Research design is the blue print for empirical research work that guides the researcher in a scientific way towards the achievement of the objectives. Survey method has supported the researcher to find the perception, usage, and awareness of credit cards among the bank customers.

\subsection{Sample Design}

Sampling design is imperative in every scientific study. Hence, the researcher decided to collect the data through multi stage sampling.

\subsection{Selection of District}

Krishnagiri was formed as $\mathbf{3 0}^{\text {th }}$ district by the Government of Tamil Nadu. It was carved out of Dharmapuri district on 09th February 2004 with five taluks and ten blocks. Krishnagiri district is bounded by Vellore and Thiruvannamalai districts in the East, Karnataka state in the west, State of Andhra Pradesh in the North Dharmapuri District in the south.

Its area is $5143 \mathrm{Sq}$. Kms. This district is elevated from $300 \mathrm{~m}$ to $1400 \mathrm{~m}$ above the mean sea level. It is located between $11^{\circ} 12^{\prime} \mathrm{N}$ to $12^{\circ} 49^{\prime} \mathrm{N}$ Latitude, $77^{\circ} 27^{\prime} \mathrm{E}$ to $78^{\circ} 38^{\prime} \mathrm{E}$ Longitude. The average rainfall is $830 \mathrm{~mm}$ per annum. March - June is summer season. July - November is Rainy Season and between December February winter prevails. Three languages namely Tamil, Telugu and Kannada are predominantly spoken in this district. Major religions are Hindu, Islam and Christianity.

\subsection{Selection of Sample Bank Branches}

Since credit card is a banking product and banks are issuing credit cards, in the analysis of awareness, respondents were selected from among the bank customers. Therefore, in the second stage, the researcher has identified the total number of commercial bank branches located in Krishnagiri District. The total number of commercial bank branches located in Krishnagiri District stood at 105 as on 31st March 2010, comprising of 81 public sector, 24 private sector banks $n$ branches as per the banking statistics published by Lead Bank Office, Indian Bank, Krishnagiri, 2009-10. These 105 bank branches constituted the sample frame for the selection of banks. Twenty per cent of these banks were selected by drawing lots by following Simple random sampling method, which came to 21. For convenience, this was rounded off 25 . Fifteen public sector and ten private sector bank branches were thus selected, the list of which is given below. 


\begin{tabular}{|c|c|c|c|c|}
\hline \multicolumn{5}{|c|}{ Table -1} \\
\hline Sl.No & Public Sector Banks & 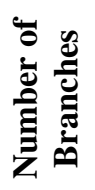 & Private Sector Banks & 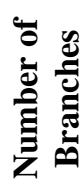 \\
\hline 1 & Andra Bank & 1 & Axis Bank & 1 \\
\hline 2 & Allahabad Bank & 1 & Catholic Syrian Bank & 1 \\
\hline 3 & Bank of India & 1 & Citi Union Bank & 1 \\
\hline 4 & Canara Bank & 1 & HDFC Bank & 1 \\
\hline 5 & Central Bank of India & 1 & ICICI Bank & 1 \\
\hline 6 & Corporation Bank & 1 & Ing Vysya Bank & 1 \\
\hline 7 & Dena Bank & 1 & The Karur Vysya Bank & 1 \\
\hline 8 & Indian Bank & 2 & Karnataka Bank & 1 \\
\hline 9 & Indian Overseas Bank & 1 & Lakshmi Vilas Bank & 1 \\
\hline 10 & Punjab National Bank & 1 & Tamilnadu Mercantile Bank & 1 \\
\hline 11 & Syndicate Bank & 1 & & \\
\hline 12 & State Bank of India & 2 & & \\
\hline 13 & Union Bank of India & 1 & & \\
\hline & TOTAL & 15 & & 10 \\
\hline
\end{tabular}

\subsection{Selection of Bank Customers}

Since the number of customers in each of the selected bank branch was more than 12000 , it was found quite unwieldy to select certain percentage of the population as the sample frame. 12 customers were selected from each of the 25 select bank branches on the basis of convenience. Thus 300 (25x12) bank customers were selected as the sample for analyzing customer awareness about credit cards.

\subsection{Selection of Credit Card Holders}

From the survey conducted by the researcher and discussions held with the bank managers, it was found that the popular brands of credit cards in Salem District were ICICI Card, SBI Card, HDFC Card, and AXIS Card. Thus it was found that the total number of credit card holders were around 3000. The researcher selected 300 credit card holders, the number working out to 10 per cent of the population. The sample respondents were selected on Convenience basis. The details of the sample covered in the study are tabulated in Table 2.

Table - 2

Composition of Sample

\begin{tabular}{|l|c|}
\hline \multicolumn{1}{|c|}{$\begin{array}{c}\text { Composition of Sample for } \\
\text { Analysing Customer Awareness }\end{array}$} & No. of Respondents \\
\hline $\begin{array}{l}\text { Bank Customers (Account holders not } \\
\text { possessing credit cards) }\end{array}$ & $\mathbf{3 0 0}$ \\
\hline $\begin{array}{l}\text { For the analysis pertaining to credit } \\
\text { card holders: }\end{array}$ & No. of Respondents \\
\hline ICICI Card holders & 87 \\
\hline HDFC Card holders & 78 \\
\hline SBI Card holders & 76 \\
\hline AXIS Card holders & 59 \\
\hline Total & $\mathbf{3 0 0}$ \\
\hline Grand Total & $\mathbf{6 0 0}$ \\
\hline
\end{tabular}

\section{Data Source: Primary Data}

The study was based on primary data. The tools constructed for the collection of data were Interview Schedule for the selected bank customers who do not possess credit cards and Questionnaire for the credit card holders. Demographic profiles pertaining to the respondents were included in Part A of the Interview Schedule and Questionnaire. Part B included questions relating to the banking related profile. Questions required for ascertaining bank customers "awareness about credit cards have been given in Part C of the Interview Schedule for the respondents not possessing credit cards. In the case of credit card holders" questionnaire, questions pertaining to credit card holding were included in Part C and the reasons for buying credit card in Part D. Part E and $\mathrm{F}$ of the questionnaire were designed to understand card holders "attitude and satisfaction towards credit 
A Study On Perception And Awareness On Credit Cards Among Bank Customers In Krishnagiri cards respectively. Questions in Part $\mathrm{G}$ and $\mathrm{H}$ included questions for ascertaining credit card holders" perception and experience regarding the role of core and supplementary services at the product level.

\subsection{Pilot Study and Pre-testing}

A pilot study was conducted on 50 respondents not possessing credit cards and 50 credit card holders in order to check the validity of the questions and to understand the difficulties of the respondents in giving their responses. On the basis of the pilot study, the interview schedule and questionnaire were redesigned with suitable modification.

\subsection{Field Work, Data Collection, and Processing of Data}

The researcher undertook field work during the period from May 2009 to May 2011. By using the interview schedule, the researcher interviewed the bank customers who do not possess credit cards. Interviews were conducted at the bank premises with the permission of the bank managers concerned. The questionnaire was issued to the credit card holders. The credit card holders were contacted in the bank premises, at ATM Centres and mercantile establishments and the data were collected. The data thus collected were posted in the master table to facilitate further processing. Statistical analysis of the data was done through SPSS software in computer.

\subsection{Quantification and Measurement of Variables and Construction of Scales}

The first objective of the study is to determine customer awareness about credit cards. Customer awareness was measured on a three point scale. The scores awarded were for the responses fully aware and full knowledge- 3 each, aware to a certain extent and just heard of responses- 2 each and for not aware and not heard of responses-1 each. In the analysis of the usage pattern of credit cards, a five point scale was used. Scores were allotted for the usage such as very often-5, often-4, occasionally-3, rarely-2, and very rarely-1. For determining the attitude of card holders towards credit cards "Fishbeins Attitude Model" has been adopted. Belief score and evaluation score were measured on bipolar scales.

The sixth objective of the study is to measure the satisfaction of the credit card holders which has been measured by constructing a scale. In this scale 9 components of satisfaction have been included under three heads namely issue of credit cards, operation of credit cards, and charges on credit cards. A five point scale on the "Likert Model" has been constructed. The scores awarded to the responses of each component were, highly satisfied-5, satisfied-4, No opinion-3, dissatisfied-2, and highly dissatisfied-1. The total of the scores of the three components under each head constitutes the satisfaction score of the respondent for that head.

The total scores awarded for all the 9 components of the three heads constitute the overall satisfaction score of each respondent. Further, mean satisfaction scores have been ascertained and standard deviation determined. Level of satisfaction has been classified into low, moderate, and high. The respondents with satisfaction score up to mean minus standard deviation have been grouped under low satisfaction, those respondents with their respective score above mean plus standard deviation under high satisfaction, and respondents with scores between these two limits under moderate satisfaction. For the purpose of seventh objective of the study, for understanding card holders' perception and experience towards core services, facilitating services and supporting services, scores were allotted on a three point scale such as 3,2 , and 1 for responses 'yes', 'somewhat', and 'no' respectively.

\subsection{Statistical Tools}

Statistical tools such as Chi-square Test, Multiple Regression, Discriminant Function Analysis, Analysis of Variance (ANOVA) and T test were used in the study.

\subsubsection{Chi-Square Test}

In order to study the interrelationship among influence of demographic variables and banking related profile of the respondents over the possession of credit cards, chi-square test has been applied. Chi-square test has also been applied in the analysis of the extent of usage of credit cards.

\subsubsection{Weighted Average Analysis}

Weighted average analysis has been used in the present study to determine the perception and experience scores for the scores for the core services, facilitating services and supporting services offered to card holders.

\subsection{3 ' $t$ ' Test}

In order to know whether there is significant gap between the mean scores for card holders" perception and experience about the credit card core services, facilitating services, and supporting services ' $t$ ' test has been employed. 
A Study On Perception And Awareness On Credit Cards Among Bank Customers In Krishnagiri VI.

Observations and Inference

6.1 Customers' Awareness Level

Table - 3

Awareness Score

\begin{tabular}{|l|l|l|}
\hline $\begin{array}{c}\text { Awareness Criteria } \\
\text { related to Credit Cards }\end{array}$ & Total Score & Mean Score \\
\hline Brands & 5988 & 9.98 \\
\hline $\begin{array}{l}\text { Conditions, charges and } \\
\text { services }\end{array}$ & 5706 & 9.51 \\
\hline Benefits & 6924 & 11.54 \\
\hline Overall & 18618 & 31.03 \\
\hline
\end{tabular}

As per Table 3 mean awareness score for credit card benefits stood higher at 11.54 followed by awareness about the brands of credit cards (means score 9.51) and awareness about conditions, charges, and services.

Though the bank staff gives clear details about the benefits of credit cards to the bank customers, they do not provide clear information about the conditions, charges, and services of the credit cards.

\subsection{Frequency of Usage of Credit Cards and Satisfaction - Mean Satisfaction Scores}

Table 4

\begin{tabular}{|c|c|c|c|c|c|}
\hline \multirow{2}{*}{$\begin{array}{c}\text { Frequency of Usage } \\
\text { of Credit Cards }\end{array}$} & $\begin{array}{c}\text { Number of } \\
\text { Respondents }\end{array}$ & $\begin{array}{c}\text { Issue of } \\
\text { Credit } \\
\text { Cards }\end{array}$ & $\begin{array}{c}\text { Operation } \\
\text { of Credit } \\
\text { Cards }\end{array}$ & $\begin{array}{c}\text { Charges on } \\
\text { Credit } \\
\text { Cards }\end{array}$ & $\begin{array}{c}\text { Overall } \\
\text { Score }\end{array}$ \\
\hline Regular & $79(27)$ & 11.859 & 12.293 & 11.463 & 35.613 \\
\hline Occasional & $221(73)$ & 12.378 & 12.609 & 11.009 & 35.996 \\
\hline
\end{tabular}

Note: Figures in bracket show percentage

Differences in the mean satisfaction scores were observed from Table 4 for all the heads of satisfaction.

\section{ANOVA (F- Test)}

The significance of the differences in the mean scores were analyzed through ANOVA technique. The following null hypothesis has been formulated in this connection.

Hypothesis: Mean satisfaction scores of credit card holders do not vary significantly according to the frequency of usage of their credit cards.

Table 5

Summary of ANOVA 'F' Ratio for Frequency of Usage

Credit Cards and Satisfaction

\begin{tabular}{|c|c|c|c|c|c|c|}
\hline \multicolumn{2}{|c|}{$\begin{array}{c}\text { Frequency of Usage } \\
\text { and Satisfaction }\end{array}$} & df & $\begin{array}{l}\text { Sum of } \\
\text { Squares }\end{array}$ & $\begin{array}{c}\text { Mean } \\
\text { Square }\end{array}$ & $\mathbf{F}$ & $\begin{array}{c}\text { Significance } \\
\text { at } 1 \% \text { level }\end{array}$ \\
\hline \multirow{3}{*}{$\begin{array}{c}\text { Issue of } \\
\text { Credit Cards }\end{array}$} & $\begin{array}{c}\text { Between } \\
\text { Groups }\end{array}$ & 1 & 20.991 & 20.991 & 16.259 & \multirow{3}{*}{ Significant } \\
\hline & $\begin{array}{l}\text { Within } \\
\text { Groups }\end{array}$ & 298 & 772.018 & 1.291 & & \\
\hline & Total & 299 & 793.009 & & & \\
\hline \multirow{3}{*}{$\begin{array}{l}\text { Operation of } \\
\text { Credit Card }\end{array}$} & $\begin{array}{c}\text { Between } \\
\text { Groups }\end{array}$ & 1 & 7.799 & 7.799 & 4.805 & \multirow{3}{*}{$\begin{array}{c}\text { Not } \\
\text { Significant }\end{array}$} \\
\hline & $\begin{array}{l}\text { Within } \\
\text { Groups }\end{array}$ & 298 & 970.554 & 1.623 & & \\
\hline & Total & 299 & 978.353 & & & \\
\hline \multirow{3}{*}{$\begin{array}{l}\text { Charges of } \\
\text { Credit Cards }\end{array}$} & $\begin{array}{c}\text { Between } \\
\text { Groups }\end{array}$ & 1 & 15.998 & 15.998 & 3.468 & \multirow{3}{*}{$\begin{array}{c}\text { Not } \\
\text { Significant }\end{array}$} \\
\hline & $\begin{array}{l}\text { Within } \\
\text { Groups }\end{array}$ & 298 & 2758.574 & 4.613 & & \\
\hline & Total & 299 & 2774.572 & & & \\
\hline
\end{tabular}

Issue of Credit Cards: The table 5 shows the ANOVA result that the calculated F-ratio value is 16.259 which is more than the table value of 6.64 at $1 \%$ level of significance. Since the calculated value is more than the table 
A Study On Perception And Awareness On Credit Cards Among Bank Customers In Krishnagiri value, it is inferred that there is significant difference between credit card holders' frequency of usage and their level of satisfaction on issue of credit cards. Hence, the null hypothesis is rejected.

\subsection{Weighted Average Analysis}

To estimate and compare the card holders' mean perception and experience scores related credit card services such as core services, facilitating services and supporting services, weighted average analysis is performed using three point rating scale assigning 3, 2, 1 points for card holders' responses 'yes', 'somewhat', and 'no' respectively, and the results are presented in the following table 6

Table 6

Card Holders' Perception and Experience - Weighted Average Scores

\begin{tabular}{|c|c|c|c|c|c|}
\hline \multirow{2}{*}{$\begin{array}{l}\text { Types of } \\
\text { Services }\end{array}$} & \multicolumn{2}{|c|}{ Statement No. } & \multirow{2}{*}{$\begin{array}{l}\text { Perception } \\
\text { Score }\end{array}$} & \multirow{2}{*}{$\begin{array}{c}\text { Experience } \\
\text { Score }\end{array}$} & \multirow{2}{*}{ Gap } \\
\hline & Perception & Experience & & & \\
\hline \multirow{3}{*}{$\begin{array}{c}\text { Core } \\
\text { Services }\end{array}$} & 7.1 & 8.1 & 2.8625 & 2.8550 & 0.0075 \\
\hline & 7.2 & 8.2 & 2.9275 & 2.9275 & $\begin{array}{c}- \\
0.0200\end{array}$ \\
\hline & 7.3 & 8.3 & 2.9600 & 2.9650 & $\begin{array}{c}- \\
0.0050\end{array}$ \\
\hline Mean & & & 2.9100 & 2.9158 & $\overline{-}$ \\
\hline \multirow{2}{*}{$\begin{array}{c}\text { Facilitating } \\
\text { Services }\end{array}$} & 7.4 & 8.4 & 2.4350 & 2.2475 & 0.1875 \\
\hline & 7.5 & 8.5 & 2.2975 & 2.8950 & 0.0325 \\
\hline Mean & & & 2.68125 & 2.57125 & 0.1100 \\
\hline \multirow{2}{*}{$\begin{array}{c}\text { Supporting } \\
\text { Services }\end{array}$} & 7.6 & 8.6 & 1.4500 & 1.4150 & 0.035 \\
\hline & 7.7 & 8.7 & 1.3650 & 1.2375 & 0.1275 \\
\hline Mean & & & 1.4075 & 1.3263 & 0.0812 \\
\hline \multicolumn{3}{|c|}{ Overall Mean Scores } & 2.4153 & 2.3632 & 0.0521 \\
\hline
\end{tabular}

As per the above table 6 mean perception and experience scores were higher for core services when compared to the other two types of services. This is a clear indication of the fact that consumers evaluate the credit card purchase decision based more upon core benefits of credit card. Next to core services the mean perception and experience scores facilitating services stood higher which implies that these services also are considered important by consumers to evaluate the credit card purchase. As regards supporting services low mean scores indicate that there is less consideration for supporting services as a criterion for purchase of credit cards.

Core services which are perceived more are revolving credit and the feeling of reduced risk of carrying cash. In fact consumers experience these core services at higher levels than their perception which are evident from the higher experience scores.

\section{Limitations of the Study}

This study is subject to the following limitations

i. The study covers individual card holders only. Corporate card holders have been excluded from this study.

ii. Credit card holders of Foreign Sector Banks have not been brought under the purview of the study, since there is no Foreign Sector Bank in Salem District.

iii. Credit card holders and non-holders who do not have bank account are not included in this study.

\section{Customer Awareness about Credit Cards}

\section{Findings}

It is observed from the analysis of bank customers' awareness about credit cards that ICICI credit cards are more popular which follwed is by SBI Card and HDFC Card. Can Card is found to be less popular among the sampled respondents. Regarding the source of information about credit cards the respondents' revealed that the agents of ICICI bank were the source of information about ICICI card. In the case for SBI Card, advertisements provided the necessary knowledge and for HDFC cards, the bank was the source of necessary information for the customers.

Regarding the conditions and charges on credit cards, majority (64\%) are aware of the basic conditions and 76 percent of the respondents know about the charges imposed on the services. Cash withdrawal facility on credit cards is not known to majority $(68 \%)$ of the respondents. None of the sampled respondents have awareness about the interest free credit period. 
A Study On Perception And Awareness On Credit Cards Among Bank Customers In Krishnagiri

Majority (88\%) of the sampled non-holders of credit card are aware of the convenience in using credit cards, reducing the risk of carrying cash $(74 \%)$ and wider acceptance of the credit cards $(67 \%)$. Higher proportions of the respondents $(79 \%)$ know about the ATM facility for cash withdrawal. As regards demography and level of awareness, it is observed that age wise majority of the middle aged (68\%), gender wise - the male (73\%), education wise- the college educated (84\%), occupation wise- the employed (67\%), and income wise- the higher income group ( $81 \%$ ) have high level of awareness. High proportions of the low awareness category comprised of those above 50 years old, female customers, school educated category, agriculturists by occupation, and the low income earners.

Regarding banking related profile of the respondents and their level of awareness, the study shows that majority of the bank customers with long period of customership (72\%), those transacting more frequently with the bank (78\%), those who have current account with the bank (76\%), and customers with larger balance in their account know more about credit cards and their awareness level is found to be high. Low awareness category comprised of more of customers with short period customership (64\%), those transacting less frequently (58\%), fixed deposit account holders (68\%), and customers with smaller balance in their account (52\%).

Promotional measures through agents, banks' services, advertisement and merchant establishments are the sources of information and awareness providers for bank customers.

\section{Determinants of Credit Limits}

The eligible credit limits of majority (68\%) of the respondents ranged from Rs.15,000 to Rs. 50,000. Credit limit actually availed were found to be ranging from Rs.15,000 to Rs. 30,000 in the case of majority (54\%) of the card holders. Correlation analysis conducted to test the degree of relationship between the socioeconomic characteristics of credit card holders and credit limit actually availed revealed that the credit limit availed by the card holders is significantly and positively correlated with monthly income of the card holders, their family size, and total family expenditure. The implication is that higher the income, the family size, and the total expenditure, the credit limit actually availed is on the higher side. The actual credit limit availed is independent of the card holders occupation as well as education.

Multiple regression model used to find out the determinants of the credit limits availed by the credit card holders indicated that card holders' income is the most significant factor determining the actual credit limit availed by the card holder. This variable explained the variation of the credit limit availed to the extent of $51.9 \%$.

\section{Attitude of Card Holders towards Credit Cards}

Attitudinal behavior of credit card holders determined based on 'Fishbein's Attitude Model' indicated that majority of the sampled credit card holders $(71.20 \%)$ have positive attitude towards credit cards. 'Availability of emergency funds through credit cards' and 'shopping without paying cash immediately' contributed more towards the positive attitude of card holders. However, 28.80 percent of the card holders have negative attitude and higher rate of interest charged is the cause of this negative attitude.

Regarding the demographic and credit card related variables influencing card holders' attitude the logit analysis revealed that two variables namely credit card holders' family income and eligible credit limit significantly influenced their attitude. This is understandable in view of the economic conditions of the card holders.

\section{Card Holders' Perception and Experience}

The analysis pertaining to card holders' perception and experience regarding the role of core and supplementary service elements show that majority of the sampled credit card holders $(87.25 \%)$ consider credit cards as a convenient mode of payment and $90.75 \%$ consumers carry the feeling of reduced risk of carrying cash and $96 \%$ consider revolving credit in evaluating purchase of credit cards.

Facilitating service of easy acceptability procedure of credit cards at retail outlets is considered by majority (92.75\%) of the respondents while making purchase decisions of credit cards.

Presence of additional features (supporting services) of free insurance coverage and discounts have not been strongly felt by majority $(69.75 \%$ and $78.25 \%)$ of the card holders.

Card holders' experiences were very high regarding all the core services such as convenience in payment $(86.25 \%)$ reduced risk of carrying cash $(92.75 \%)$ and revolving credit facility $(96.5 \%)$. Facilitating services of easy acceptability at retail outlets have also been experienced by majority $(94.50 \%)$ of the card holders. The importance of supporting services of free insurance coverage and added discounts were not actually experienced by majority $(70.25 \%$ and $85.75 \%)$ of the card holders.

Thus the analysis revealed that respondents considered basic benefits, facilitating services and supporting services prior to purchase of credit cards. However, facilitating services were of low consideration. 


\section{Suggestions}

Based on the findings of the study the following suggestions are made here:

\section{Popularizing the Credit Cards}

Can Card is found to be less popular among the respondents. Hence methods should be adopted to bring a higher degree of popularization of this credit card through mass media channel like television, radio, railway centers, and super markets with a pictorial review of the card facility.

\section{Creating Awareness about Interest Free Credit Period}

The most lucrative feature of a credit card is the interest free credit period offered to card holders. Nonholders of credit cards are not aware of this benefit of credit cards. Hence awareness should be created about this benefit of credit cards among the non-holders.

\section{Direct Marketing}

Credit card issuers, though offer international levels of service and credit support to the card holders, have failed to make an impression among the less educated and the agricultural category with middle level income. They also feel that the cost of credit cards is high and therefore make it a status symbol rather than meeting their needs. Hence, direct marketing by the banking clubbed with other services will be helpful to impress this untapped segment.

\section{Implementing Regulatory Measures}

The credit limit availed by many card holders are found to be less than their eligibility limits. The working group on regulatory mechanism for credit cards has suggested measures aimed at encouraging card usage in a safe and secure manner. This guideline should be implemented so that the entire eligible credit limit may be availed by the card holders.

\section{Extending Incentives to all Types of Cards}

Despite more widespread usage, most of the credit card users are the more educated with professional types of jobs and high income earners. Most of the card holder incentives are offered for high value cards. Hence it is suggested that incentives should be extended to all types of cards to promote greater usage of credit cards like 'Exclusive' and 'Silver held by lower and middle income earners.

\section{Providing More Facilitating Services}

It is found from the analysis made in the study that supplementary services are perceived more as the expected features of the credit card by the card holders. Hence maximum supplementary service elements should be added to the credit cards.

\section{Providing Knowledge about Supporting Services}

It is identified from the study that respondents did not consider the supporting services for purchase evaluation. This is due to inadequate information regarding supporting services. Providing knowledge about supporting services to customers can help the marketers to develop an advantage for themselves in the market Visa Vis other players.

\section{Reducing Interest Rates}

One of the reasons for low level of satisfaction of card holders has been the high rates of interest which the card holders are actually paying ranging from 36 to 45 percent. Hence it is suggested that these rates be brought down.

\section{Making the Internal Control System Effective}

With the average credit limit of Rs.10,000 to Rs. 30,000 the credit cards have not made an attractive case of fraudsters, still a few cases of credit card frauds ( $02 \%)$ have been reported in the study. Hence banks are advised to implement the „Internal Control System' formulated by the RBI effectively to combat frauds.

\section{Conclusion}

The credit card issue in terms of number of credit cards witnessed a whopping growth during the past five years. In terms of key players ICICI has notched the landmark figure of 90 lakh credit cards by 2008 taking the position of number one player in the segment. It is further concluded that there are a number of bank customers who do not have any knowledge about credit cards. Many people have knowledge about credit cards, but do not possess credit cards because of the fear of falling into debt trap. High income earners and highly educated class use credit cards more, availing high credit limits.

Extent of usage of credit cards is smaller among higher proportion of the card holders. Customers' satisfaction is found to be less because of high rate of interest. Customers perceived core services and facilitating services at higher level. Card holders face the major problem of lack of proper advice from banks. Credit card market is yet to realize its potential.

The scenario of credit cards during 2009-2010 is very significant. Many card holders surrender their credit cards and instead of using credit cards the banks"e customers prefer debit cards. The debit cards too help them avoid carrying cash and enable withdrawal of cash through ATM and they need not be afraid of falling into debt trap as in the case of credit cards. Due to financial inflation, many banks have stopped issuing credit 
A Study On Perception And Awareness On Credit Cards Among Bank Customers In Krishnagiri cards to their customers. As people are yet to realize the complete potential of credit card, its market is falling down.

\section{BOOKS:}

\section{References}

[1]. Arunajatesan.S and Radhakrishnan (2009), "Bank Management”, Margham Publications, Chennai-600017, PP 3.10-3.24.

[2]. Balaji .S (1999), "Services Marketing and Management”, S.Chand \& Co Ltd. (An ISO 9001:2000 Company), New Delhi-110002, PP.85-92.

[3]. Bhalla V.K. (2005), "Management of Financial Services 2005”, an Mol Publications Pvt, Ltd., New Delhi - 110002, PP 30-38.

[4]. Collier, D.A (1994), “The Service/Quality Solution”, Irwin Professional Publishers, Distributors by IBD, New Delhi-110007, PP 166-175.

[5]. Dibakar (1999), "Marketing of Plastic Money”, Kanishka Publishers, New Delhi-110005, PP67-74.

[6]. Foster (2007), “101 ways to Boost Customer Satisfaction - 2007” KOGAN Page Ltd., New Delhi-110015, PP 15-22.

[7]. Gupta, S.L. "Marketing Sense”, S\&S Publications, New Delhi-110010, PP 123-131.

[8]. Gurusamy S (2004), "Financial Servicecs and Markets", Thomson Asia Pvt. Ltd, New Delhi-110014, PP.55-67.

[9]. HBF (2005), "General Bank Management”, Mc Millan, India Ltd., P 46.

[10]. Jha. S.M. (2007), “Services Marketing”, Himalaya Publishing House, Mumbai-400005, PP45-56.

Highly satisfied

Satisfied

No opinion

Dissatisfied

Highly dissatisfied

Overall Satisfaction Scale

Overall score

Number of card holders

Overall mean score

Standard deviation

Mean plus standard deviation

Mean minus standard deviation

Scores above 39.225

Scores up to 32.9885

Scores from 33 to 39

Satisfaction Scale - Issue of Credit Cards

Total scores

Number of card holders

Mean satisfaction score

Standard deviation

Mean plus standard deviation

Mean minus standard deviation

Scores above 13.805

Scores up to 11.245

Scores from 12 to 13

\section{Satisfaction Scale - Operation of Credit Cards}

Total scores

Number of card holders

score

deviation

deviation

Mean minus standard deviation

Scores above 13.819

Scores up to 10.661

Scores from 11 to 13

Satisfaction Scale - Charges on Credit Cards

Total scores

Number of card holders

Mean satisfaction score

Standard deviation

Mean plus standard deviation

\section{Appendices}

$$
-5
$$

$$
\begin{aligned}
& -4 \\
& -3 \\
& -2 \\
& -1
\end{aligned}
$$$$
-21665
$$

$-600$

$$
-36.107
$$

$-3.1185$

$-36.107+3.1185=39.2255$

$-36.107-3.1185=32.9885$

- High level of satisfaction.

- Low level of satisfaction.

- Medium level of satisfaction.

$-7515$

$-600$

-12.525 .

$-1.280$

$-12.525+1.280=13.805$

$-12.525-1.280=11.245$

- High level of satisfaction.

- Low level of satisfaction.

- Medium level of satisfaction.

- 600 Mean satisfaction

- 12.24 Standard

- 1.579 Mean plus standard

$-12.24+1.579=13.819$

$-12.24-1.579=10.661$

- High level of satisfaction.

- Low level of satisfaction.

- Medium level of satisfaction.

$$
\begin{array}{ll}
-600 & -6806 \\
-11.342 & \\
& -1.626 \\
& -11.342+1.626=12.968
\end{array}
$$


A Study On Perception And Awareness On Credit Cards Among Bank Customers In Krishnagiri

Mean minus standard deviation

Scores above 12.968

Scores up to 9.716

Scores from 10 to 12
$-11.342-1.626=9.716$

- High level of satisfaction.

- Low level of satisfaction.

- Medium level of satisfaction.

\section{Perception and Experience Scores}

Scores allotted to the responses for statements given in Part G 7.1 to 7.7 and Part $\mathrm{H}$ 8.1 to 8.7 of the questionnaire.

Yes

Somewhat

No

\begin{tabular}{|l|c|}
\hline \multicolumn{1}{|c|}{ Perception } & Total Score \\
\hline Core Services & 1746 \\
\hline Facilitating Services & 1609 \\
\hline Supporting Services & 845 \\
\hline Experience & Total Score \\
\hline Core Services & 1749 \\
\hline Facilitating Services & 1543 \\
\hline Supporting Services & 797 \\
\hline
\end{tabular}

